\section{COMPARING TWO SEARCC MEMBER CODES OF ETHICS: ACS AND SCS}

\author{
Shirley Wheeler ${ }^{1}$
}

\begin{abstract}
The South East Asian Regional Computer Confederation (SEARCC) Code of Ethics provides standards for its members, and this includes the establishment of a congruent code of conduct for each member organization. The degree to which the Australian and Singaporean professional codes of ethics and conduct are reflective of the SEARCC Code of Ethics will be examined in this paper. A new systemic approach to applied ethics will be used for this exercise. Points of comparison and contrast between the two Member codes will be considered. Some implications for more global compatibility in IS-related codes of ethics are drawn.
\end{abstract}

\section{Introduction}

As the South East Asian confederation of national information technology professional societies, the SEA Regional Computer Confederation (SEARCC) claims to be 'nonpolitical and non-profit-making', operating by consensus (http://www.searcc.org). It recognises that there exist 'fundamental differences' among its membership 'in regard to strategy, national goals and technology paths as well as stages of development in the use of technology'

1 School of Accounting and Information Systems University of South Australia, Australia (http://www.searcc.org). Yet, its members are expected to conform to the letter and spirit of the SEARCC Code of ethics (SEARCC Code of Ethics). The extent to which two of the Members' codes do conform is examined in this paper. The Singapore Computer Society (SCS) was one of the six founding signatories to the Charter and Constitution of the SEARCC in Singapore in 1978, whereas the Australian Computer Society (ACS) developed its code from a more western tradition. Using a newly developed analysis methodology, the SEARCC Code of Ethics, and also the SCS Code of Professional Conduct and the ACS Code of Ethics will be compared in this paper. Implications for more global congruence in information technology codes of ethics are considered.

\section{Methodology}

The culturally inclusive inquiry headings of 'soft' systems information systems methodology (SSM) (Checkland \& Holwell 1998) are used as information technology (IT) stakeholders. Different parts of IT codes of ethics apply more readily to different types of stakeholders, although all parts of the code do apply to all, so there is room for considerable overlap and interpretation as to which parts of the code best apply to which stakeholders. The seven SSM headings are used as: a convenient way of mapping the various IT codes of ethics, as a way of analysing the content of the codes, to facilitate comparison between the codes and to identify gaps and areas for improvement (Wheeler 2004). These seven SSM inquiry headings, along with a brief explanation of the stakeholder role they capture, are as follows: Customer, Actor, Transformation, Worldview, Owner, Environment, Accountability (CATWOEA) (Wheeler, 2004). These can be rearranged to put the owner first, as the owner has the general 
overview of the organization involved, and also each individual owns his or her own story.

A grammatical framework is used to cover all of the different roles within the narrative of an IS development, including all of the stakeholder categories that will be affected by the IS. The main parts of speech are covered by the reporter or storyteller's seven question words: 'who', 'what', 'when', 'where', 'why', 'how', 'how much?' (or 'to what extent?', 'how long?', etc.). While the story involved changes according to the perspective from which it is told, the following general story illustrates how the seven inquiry headings, the seven headings of soft systems IS methodology and the basic ethical approaches can be conceptually mapped together (Wheeler 2003):

Owner - Relates to a general overview perspective, with concern for ethical integrity in relation to the highest goals of business leadership, including responsibility for the organizational effects on all the stakeholders. In the general story, the owner can be viewed as the main 'who' involved.

Worldview - Relates to the stakeholders with assumptions that influence a computer project. The worldview heading can be seen as relating to the need to avoid unnecessary offence in business speech and culture, as well as the worldview assumptions and related objectives of management and colleagues. This role could be viewed as 'what' needs to be taken into consideration.

Customer - Relates to respect for client's well-being, property and wealth. The IT professional needs to consider each customer 'when' working on a customer-related project.

Actor - Relates to staff culture and stakeholder relationships, including professionalism, as the actors undertake the 'how' of a professional task.

Transformation - Relates to business strategies and respect towards stakeholders in a situation of change and possibly some stress, particularly those that may seem obstructive. Ethically, it evokes a transformational intent on improvement, rather than a devaluation of stakeholders who are not viewed as helpful. As the professional task is completed, so is the ethical goal of 'why'.

Accountability - Relates to the evaluation of business practice, such as in annual reports and internal reporting procedures, together with appropriate means and procedures for the redress of unethical behaviour (evaluation of ethical practice). This could be viewed as 'how much' the various perspectives are taken into consideration and held accountable.

Environment - Extends ethical consideration to the humblest creature in the environment, including habitat needs and environmental quality, and could be regarded as the 'where' of ethics.

As the codes of ethics are theoretical in nature until put to a practical application, the main theoretical aspects of ethics have the most relevant application to the codes of ethics. These main ethical theories are:

Deontological ethics, which relates to laws, principles and duties; 
Teleological ethics, which relates to ethical goals; and

Virtue ethics, which relates to the inherent characteristics of an ethical agent (Wheeler 2004).

Most codes of ethics focus on deontological ethics, as the codes give advice on actions that are expected of members of professional societies. Some parts of the codes of ethics aspire to ethical outcomes, such as utilitarianism, which involves consideration of the greatest amount of good or welfare that can be produced. Usually, there is some mention of ethical virtue in a comprehensive code of professional ethics or conduct, as even 'professionalism', can be considered to be an ethical virtue. Virtue ethics can be viewed as coming closer to the spirit, rather than the letter of the law. For example, the ethical virtue of 'integrity' covers a wide range of deontological behaviours, as is illustrated in the SCS Code of Professional Conduct, point 1, which has four deontological points that expand on the 'integrity' heading.

Other applied ethical theories and tools include: moral relativity, situational ethics, contractarianism and ethical decisionmaking tools (Wheeler 2004). Moral relativity is contrasted to ethical norms, such as those espoused in a code of ethics, yet given ethical norms usually require some situational or contextual interpretation or adaptation. In the SEARCC Code of Ethics, the scope for moral relativity among Members is addressed by requiring respect for Member's cultural differences, while at the same time encouraging adherence to the over-arching guidance of the SEARCC Code's norms. Situational ethics is summarized in the famous saying: 'When in Rome, do as the Romans do', which may have been influenced by the brutal justice system of 'Pax Romana' ('Roman Peace'): an unpleasant fate may have awaited those who violated Roman customs when in Rome in those days. In the SEARCC context, situational ethics may mean taking into consideration the environment in which one is working, and adapting to the ethical needs of the stakeholders in this environment, including their physical survival and social needs. Contractarianism in ethics applies to contractual arrangements, such as work contracts, or the social contract, which can be viewed as giving one a right to continue to act in a civil society (Kymlicka in Singer 1991). Ethical decision-making tools include models and decision checklists that assist with covering all the ethical bases and resolving any identified ethical conflicts along the way. The choice of ethical decision-making tool can affect the quality of the ethical decision made. Such context-reliant ethical tools and the theories that inform them have most relevance when practical ethical problems are tackled. When considering general codes of ethics, they have little relevance.

So, the methodology involves analyzing the codes of ethics according to the 'CATWOEA' group of stakeholder inquiry headings on the vertical axis, which covers stakeholder ethics, and then considers which deontological, teleological and virtue ethics aspects of the codes best fit with the different stakeholder categories already identified. There is obviously going to be overlap, as all of the code of ethics does apply to all of the stakeholders, and different readers will view different parts of these codes of ethics as having more relevance to one or more groups of stakeholders at that time. However, the most important aspect of the analysis is that all parts of the code of 
ethics are included in the analysis process, and there is some reasonable justification provided for how the various parts of the code of ethics are allocated to the various headings in the analysis process. If the same person does the analysis, as has been the case in this paper, then there is some grounds for consistency of analysis between the comparisons of different codes. If more than one person is involved in the analysis, then there may be more grounds for debate, but the different parts of the code can be added in to the modeling process with enriching overlap, making the analysis process more inclusively comprehensive, rather than divisive. How this works in an analysis of the SEARCC Code of Ethics, and two of its Member Codes, is shown in the following sections of the paper.

\section{The SEARCC code of ethics}

As the SEARCC Code of Ethics is a regional, over-arching code of ethics, its guidance is very general in nature. It does recognise that there is a wide range of cultural and developmental differences between its various members, and strives to promote harmonious interaction and contribution for the mutual benefit of all Members and for the region itself. Members can contribute to improvements in the SEARCC Code of Ethics, where these are deemed to be needed, and also confirm its usefulness in regular Member forums. The SEARCC Code is analysed in the following Table.

Table 1: SEARCC Code of Ethics analysed according to 'soft' systems CATWOE inquiry headings and also three main ethical theories

\begin{tabular}{|c|c|c|c|}
\hline & Deontological Ethics & $\begin{array}{c}\text { Teleological } \\
\text { Ethics }\end{array}$ & Virtue Ethics \\
\hline Customer & $\begin{array}{l}\text {-foster an environment of } \\
\text { goodwill and co-operation and } \\
\text { assist other Members in } \\
\text { SEARCC in all ways possible } \\
\text { and provide freely any } \\
\text { guidance that is necessary and } \\
\text { within their ability (3.2) } \\
\text {-encourage understanding of } \\
\text { information technology (Gen. } \\
\text { Guidelines 6) }\end{array}$ & $\begin{array}{l}\text { - an environment of } \\
\text { goodwill and } \\
\text { cooperation (3.2) }\end{array}$ & $\begin{array}{l}\text { Goodwill (3.2) } \\
\text { Cooperation (3.2) }\end{array}$ \\
\hline $\begin{array}{l}\text { Actor- } \\
\text { Members }\end{array}$ & $\begin{array}{l}\text { - accept full responsibility and } \\
\text { obligation for any work } \\
\text { assigned to or accepted by } \\
\text { them in the specific or broad } \\
\text { interests of Members }(2.2) \\
\text { - act with trust and good faith } \\
\text { towards each other (3.1) } \\
\text { - foster an environment of } \\
\end{array}$ & - an environment of & $\begin{array}{l}\text { Responsibility (3.1) } \\
\text { Trust (3.1) } \\
\text { Good faith (3.1) } \\
\text { Goodwill (3.2) } \\
\end{array}$ \\
\hline
\end{tabular}




\begin{tabular}{|c|c|c|c|}
\hline & Deontological Ethics & $\begin{array}{c}\text { Teleological } \\
\text { Ethics }\end{array}$ & Virtue Ethics \\
\hline & $\begin{array}{l}\text { goodwill and co-operation and } \\
\text { assist other Members in } \\
\text { SEARCC in all ways possible } \\
\text { and provide freely any } \\
\text { guidance that is necessary and } \\
\text { within their ability (3.2) } \\
\text { - conduct all dealings with } \\
\text { fellow members in a } \\
\text { professional manner (3.3) } \\
\text { - respect the confidentiality of } \\
\text { information shared by other } \\
\text { Members (3.4) } \\
\text { - expected to achieve the } \\
\text { highest quality in both the } \\
\text { process and products of their } \\
\text { professional work (Gen, } \\
\text { Guidelines 1) } \\
\text { - maintain and improve their } \\
\text { professional competence (Gen, } \\
\text { Guidelines 2) } \\
\text { - comply with existing laws } \\
\text { pertaining to professional work } \\
\text { in any country in which they } \\
\text { practice (Gen, Guidelines } 3 \text { ) } \\
\text { - encourage understanding of } \\
\text { information technology (Gen. } \\
\text { Guidelines 6) } \\
\text { misrepresentation of facts on } \\
\text { information technology (Gen, } \\
\text { Guidelines } 7 \text { ) }\end{array}$ & $\begin{array}{l}\text { goodwill and } \\
\text { cooperation (3.2) } \\
\text { - highest quality } \\
\text { in ... products } \\
\text { (Gen, Guidelines 1) } \\
\text { - maintenance and } \\
\text { improvement of } \\
\text { professional } \\
\text { competence } \\
\text { (Gen, Guidelines 2) }\end{array}$ & $\begin{array}{l}\text { Cooperation (3.2) } \\
\text { Professionalism (3.3) } \\
\text { Respectfulness (3.4) } \\
\text { Professionalism } \\
\text { (Gen, Guidelines 1) } \\
\text { Professionalism } \\
\text { (Gen, Guidelines 2) }\end{array}$ \\
\hline Transformation & $\begin{array}{l}\text { - foster an environment of } \\
\text { goodwill and co-operation and } \\
\text { assist other Members in } \\
\text { SEARCC in all ways possible } \\
\text { and provide freely any } \\
\text { guidance that is necessary and } \\
\text { within their ability (3.2) } \\
\text { - maintain and improve their } \\
\text { professional competence (Gen, } \\
\text { Guidelines 2) } \\
\text { - encourage understanding of } \\
\text { information technology }\end{array}$ & $\begin{array}{l}\text { - an environment of } \\
\text { goodwill and } \\
\text { cooperation (3.2) } \\
\\
\text { maintenance and } \\
\text { improvement of } \\
\text { professional } \\
\text { competence } \\
\text { (Gen, Guidelines 2) }\end{array}$ & $\begin{array}{l}\text { Goodwill (3.2) } \\
\text { Cooperation (3.2) } \\
\text { Professionalism } \\
\text { (Gen, Guidelines 2) }\end{array}$ \\
\hline
\end{tabular}




\begin{tabular}{|c|c|c|c|}
\hline & Deontological Ethics & $\begin{array}{c}\text { Teleological } \\
\text { Ethics }\end{array}$ & Virtue Ethics \\
\hline & $\begin{array}{l}\text { (Gen, Guidelines 6) } \\
\text { - counter misrepresentation of } \\
\text { facts on information } \\
\text { technology } \\
\text { (Gen, Guidelines 7) }\end{array}$ & & \\
\hline Worldview & $\begin{array}{l}\text { - conform to the letter and the } \\
\text { spirit of the Code }(1.1) \\
\text { - act in a manner that supports } \\
\text { the aims of SEARCC }(1.2)\end{array}$ & $\begin{array}{l}\text { - aims of the } \\
\text { SEARCC (1.2) }\end{array}$ & \\
\hline Owner & $\begin{array}{l}\text { - conform to the letter and the } \\
\text { spirit of the Code (1.1) } \\
\text { - act in a manner that supports } \\
\text { the aims of SEARCC (1.2) } \\
\text { - serve the common interest of } \\
\text { all other Members in } \\
\text { accordance with the aims of } \\
\text { SEARCC (2.1) } \\
\text { - strive to use their technical } \\
\text { expertise to advance human } \\
\text { welfare and the quality of life } \\
\text { for the people of the region } \\
\text { (Gen, Guidelines } 4 \text { ) }\end{array}$ & $\begin{array}{l}\text { - aims of SEARCC } \\
\text { (1.2) } \\
\text { - the common } \\
\text { interest of all other } \\
\text { Members in } \\
\text { accordance with the } \\
\text { aims of SEARCC } \\
\text { (2.1) } \\
\text { - human welfare } \\
\text { and the quality of } \\
\text { life for the people } \\
\text { of the region (Gen, } \\
\text { Guidelines 6) }\end{array}$ & $\begin{array}{l}\text { Integrity (1.3) } \\
\text { Service (2.1) } \\
\text { Beneficence } \\
\text { (Gen, Guidelines 4) }\end{array}$ \\
\hline Environment & $\begin{array}{l}\text { - foster an environment of } \\
\text { goodwill and co- } \\
\text { operation ...(3.2) } \\
\text { - strive to use their technical } \\
\text { expertise to advance human } \\
\text { welfare and the quality of life } \\
\text { for the people of the region } \\
\text { (Gen, Guidelines } 4) \\
\text { - ethical obligation to assess } \\
\text { social consequences and help } \\
\text { ensure safe and beneficial use } \\
\text { of information technology } \\
\text { (Gen, Guidelines 5) }\end{array}$ & $\begin{array}{l}\text { - an environment of } \\
\text { goodwill and } \\
\text { cooperation (3.2) } \\
\text { - human welfare } \\
\text { and the quality of } \\
\text { life for the people } \\
\text { of the region } \\
\text { (Gen, Guidelines 4) } \\
\text { - safe and beneficial } \\
\text { use of information } \\
\text { technology } \\
\text { (Gen, Guidelines 5) }\end{array}$ & $\begin{array}{l}\text { Goodwill (3.2) } \\
\text { Cooperation (3.2) } \\
\text { Beneficence } \\
\text { (Gen, Guidelines 4) }\end{array}$ \\
\hline
\end{tabular}




\begin{tabular}{|l|l|l|l|}
\hline \multirow{1}{*}{ Accountability } & \multicolumn{1}{|c|}{ Deontological Ethics } & \multicolumn{1}{|c|}{$\begin{array}{c}\text { Teleological } \\
\text { Ethics }\end{array}$} & Virtue Ethics \\
\hline & $\begin{array}{l}\text { - establish a code of } \\
\text { professional conduct for the } \\
\text { membership of their respective } \\
\text { organisations, and ensure its } \\
\text { compliance with the } \\
\text { appropriate system of } \\
\text { compliance in their countries } \\
\text { (1.4) }\end{array}$ & $\begin{array}{l}\text { - compliance with } \\
\text { the appropriate } \\
\text { system of } \\
\text { compliance in their } \\
\text { countries (1.4) }\end{array}$ & \\
$\begin{array}{l}\text { - comply with existing laws } \\
\text { pertaining to professional work } \\
\text { in any country in which they } \\
\text { practice } \\
\text { (Gen, Guidelines 3) } \\
\text { - ethical obligation to assess } \\
\text { social consequences and help } \\
\text { ensure safe and beneficial use } \\
\text { of information technology } \\
\text { (Gen, Guidelines 5) } \\
\text { misrepresentation of facts on } \\
\text { information technology } \\
\text { (Gen, Guidelines 7) }\end{array}$ & $\begin{array}{l}\text { - safe and beneficial } \\
\text { technology } \\
\text { (Gen, Guidelines 5) }\end{array}$ & \\
& & \\
\end{tabular}

The ACS code of ethics and the SCS codes of professional conduct

These two Members of SEARCC have the two Tables that follow. Points of developed their Codes in different ways, yet they both purport to be in agreement interest will be discussed in the following with the SEARCC Code of Ethics. The section of the paper.

two ACS and SCS Codes are analysed in 
Table 2: Soft systems inquiry headings together with the Australian Computer Society (ACS) Code of Ethics

\begin{tabular}{|c|c|c|}
\hline & $\begin{array}{l}\text { Deontological and teleological } \\
\text { aspects of ACS Code of Ethics }\end{array}$ & $\begin{array}{l}\text { Associated virtue ethics } \\
\text { cluster examples from ACS } \\
\text { Code of Ethics }\end{array}$ \\
\hline $\begin{array}{l}\text { Owner - the eventual } \\
\text { system owner }\end{array}$ & $\begin{array}{l}\text { A Requirement: members are } \\
\text { required 'to subscribe to a set of } \\
\text { values and ideals which uphold and } \\
\text { advance the honour, dignity and } \\
\text { effectiveness of the profession of } \\
\text { information technology' } \\
4.1 \text { ' 'uphold and advance the } \\
\text { honour, dignity and effectiveness of } \\
\text { the profession of information } \\
\text { technology' in keeping 'with high } \\
\text { standards of competence and } \\
\text { ethical conduct' } \\
4.1 . c \text { 'strive to increase the } \\
\text { competence and prestige of the } \\
\text { profession' } \\
4.1 . d \text { 'use special knowledge and } \\
\text { skill for the advancement of human } \\
\text { welfare' } \\
4.5 .1 \text { 'I must endeavour to preserve } \\
\text { continuity of information } \\
\text { technology services } \\
\text { information flow in my care' } \\
4.5 .2 \text { 'I must endeavour to preserve } \\
\text { the integrity and security of the } \\
\text { information of others.' } \\
4.3 .6 \text { 'I must enhance the integrity } \\
\text { of the IT profession' } \\
4.10 .8 \text { 'I must do what I can to } \\
\text { ensure that the corporate actions of } \\
\text { the Society are in accordance with } \\
\text { this Code of Ethics.' } \\
4.10 .9 \text { 'I acknowledge my debt to } \\
\text { the computing profession and in } \\
\text { return must protect and promote } \\
\text { professionalism in information } \\
\text { technology. }\end{array}$ & $\begin{array}{l}\text { Integrity, honour, dignity, } \\
\text { professional effectiveness and } \\
\text { survival, loyalty, wisdom, } \\
\text { understanding, knowledge, } \\
\text { sincerity, consideration for } \\
\text { reputation in community } \\
4.1 . \text { a ...'honest, forthright, } \\
\text { impartial', } 4.1 . b \text { 'loyally serve the } \\
\text { community' ... } \\
4.1 . c \text { 'strive to increase the } \\
\text { competence and prestige of the } \\
\text { profession' } \\
4.1 . d \text { 'use special knowledge and } \\
\text { skill for the advancement of } \\
\text { human welfare' } \\
4.5 .1 \text { 'I must endeavour to } \\
\text { preserve continuity } \\
\text { information technology services } \\
\text { and information flow in my care' } \\
\text { cont. } \\
4.5 .2 \text { 'I must endeavour to } \\
\text { preserve the integrity and security } \\
\text { of the information of others.' } \\
4,3.6 \text { 'I must enhance the } \\
\text { integrity of the IT profession' } \\
4.10 .8 \text { 'I must do what I can to } \\
\text { ensure that the corporate actions } \\
\text { of the Society are in accordance } \\
\text { with this Code of Ethics.' } \\
410.9 \text { 'I acknowledge my debt to } \\
\text { the computing profession and in } \\
\text { return must protect and promote } \\
\text { professionalism in information } \\
\text { technology.' }\end{array}$ \\
\hline
\end{tabular}




\begin{tabular}{|c|c|c|}
\hline & $\begin{array}{l}\text { Deontological and teleological } \\
\text { aspects of ACS Code of Ethics }\end{array}$ & $\begin{array}{c}\text { Associated virtue ethics } \\
\text { cluster examples from ACS } \\
\text { Code of Ethics }\end{array}$ \\
\hline $\begin{array}{l}\text { Worldview - the } \\
\text { assumptions of those } \\
\text { with influence on the } \\
\text { IT project, such as } \\
\text { management } \\
\text { personnel }\end{array}$ & $\begin{array}{l}\text { 4.3. 'I must act with professional } \\
\text { responsibility and integrity in my } \\
\text { dealings with the community and } \\
\text { clients, employers, employees and } \\
\text { students' } \\
43.2 \text { 'I must place the interests of } \\
\text { the community above those of } \\
\text { personal and sectional interests.' } \\
43.6 \text { 'I must enhance ... the } \\
\text { respect of (the IT professions's) } \\
\text { members for each other.' } \\
48.4 \text { 'I must endeavour to } \\
\text { understand, and give due regard to, } \\
\text { the perceptions of those affected by } \\
\text { my work. }\end{array}$ & $\begin{array}{l}\text { Diplomacy, discretion, politeness, } \\
\text { deference } \\
\text { 3.2 'I must place the interests of } \\
\text { the community above those of } \\
\text { personal and sectional interests.' } \\
43.6 \text { 'I must enhance ... the } \\
\text { respect of (the IT professions's) } \\
\text { members for each other.' } \\
48.4 \text { 'I must endeavour to } \\
\text { understand, and give due regard } \\
\text { to, the perceptions of those } \\
\text { affected by my work.' }\end{array}$ \\
\hline $\begin{array}{l}\text { Customer - the } \\
\text { system's beneficiary }\end{array}$ & $\begin{array}{l}\text { 4.3.2 'I must work competently and } \\
\text { diligently for my clients and } \\
\text { employers' } \\
\text { 4.3.3 'I must be honest in my } \\
\text { representation of skills, knowledge } \\
\text { services and products.' } \\
\text { 4.6. More detail of the requirement } \\
\text { for 'competence' is provided, } \\
\text { which has some overlap with other } \\
\text { headings } \\
\text { 4.7. More detail of the application } \\
\text { of 'honesty' is provided. } \\
4.8 .2 \text { 'I must consider and respect } \\
\text { people's privacy which might be } \\
\text { affected by my work.' } \\
4.10 .1 \text { obtaining colleagues' advice } \\
\text { on competency where necessary. } \\
\text { 4.10.2 'I must not knowingly } \\
\text { engage in, or be associated with, } \\
\text { dishonest or fraudulent practices.' }\end{array}$ & $\begin{array}{l}\text { Honesty, competence, } \\
\text { trustworthiness, reliability } \\
\text { 4.3.2 'I must work competently } \\
\text { and diligently for my clients and } \\
\text { employers' } \\
4.3 .3 \text { 'I must be honest in my } \\
\text { representation of skills, } \\
\text { knowledge services and } \\
\text { products.' } \\
\text { 4.6. More detail of the } \\
\text { requirement for 'competence' is } \\
\text { provided, which has some } \\
\text { overlap with other headings } \\
4.7 . \text { More detail of the application } \\
\text { of 'honesty' is provided. } \\
4.8 .2 \text { 'I must consider and respect } \\
\text { people's privacy which might be } \\
\text { affected by my work.' } \\
4.10 .1 \text { obtaining colleagues' } \\
\text { advice on competency where } \\
\text { necessary. }\end{array}$ \\
\hline
\end{tabular}




\begin{tabular}{|c|c|c|}
\hline & $\begin{array}{l}\text { Deontological and teleological } \\
\text { aspects of ACS Code of Ethics }\end{array}$ & $\begin{array}{c}\text { Associated virtue ethics } \\
\text { cluster examples from ACS } \\
\text { Code of Ethics }\end{array}$ \\
\hline & & $\begin{array}{l}4.10 .2 \text { 'I must not knowingly } \\
\text { engage in, or be associated with, } \\
\text { dishonest or fraudulent practices.' }\end{array}$ \\
\hline $\begin{array}{l}\text { Actor }- \text { the } \\
\text { individual(s) involved } \\
\text { in the system, such as } \\
\text { information systems } \\
\text { professionals }\end{array}$ & $\begin{array}{l}43.4 \text { 'I must strive to enhance the } \\
\text { quality of life of those affected by } \\
\text { my work.' } \\
4.3 .6 \text { 'I must enhance ... the } \\
\text { respect of ... members for each } \\
\text { other.' } \\
4.5 .3 \text { 'I must respect the proprietary } \\
\text { nature of the information of others.' } \\
4.8 .1 \text { 'I must protect and promote } \\
\text { the health and safety of those } \\
\text { affected by my work' } \\
4.8 .2 \text { 'I must consider and respect } \\
\text { people's privacy which might be } \\
\text { affected by my work.' } \\
4.8 .5 \text { 'I must attempt to increase the } \\
\text { feelings of personal satisfaction, } \\
\text { competence, and control of those } \\
\text { affected by my work' } \\
4.10 .1 \text { 'I must respect, and seek } \\
\text { when necessary, the professional } \\
\text { opinions of colleagues in their areas } \\
\text { of competence.' } \\
4.10 .3 \text { 'I must not attempt to } \\
\text { enhance my reputation at the } \\
\text { expense of another's reputation.' } \\
4.10 .4 \text { 'I must co-operate in } \\
\text { advancing information processing } \\
\text { by communication with other } \\
\text { professionals, students and the } \\
\text { public, and by contributing to the } \\
\text { efforts of professional and } \\
\text { scientific societies and schools.' }\end{array}$ & $\begin{array}{l}\text { Respectfulness, congeniality, } \\
\text { faithfulness, conviviality, } \\
\text { pleasantness, helpfulness. } \\
43.4 \text { 'I must strive to enhance the } \\
\text { quality of life of those affected by } \\
\text { my work.' } \\
4.3 .6 \text { 'I must enhance ... the } \\
\text { respect of ... members for each } \\
\text { other.' } \\
4.5 .3 \text { 'I must respect the } \\
\text { proprietary nature of the } \\
\text { information of others.' } \\
4.8 .1 \text { 'I must protect and promote } \\
\text { the health and safety of those } \\
\text { affected by my work' } \\
4.8 .2 \text { 'I must consider and respect } \\
\text { people's privacy which might be } \\
\text { affected by my work.' } \\
4.8 .5 \text { 'I must attempt to increase } \\
\text { the feelings of personal } \\
\text { satisfaction, competence, and } \\
\text { control of those affected by my } \\
\text { work' } \\
4.10 .1 \text { 'I must respect, and seek } \\
\text { when necessary, the professional } \\
\text { opinions of colleagues in their } \\
\text { areas of competence.' } \\
4.10 .3 \text { 'I must not attempt to } \\
\text { enhance my reputation at the } \\
\text { expense of another's reputation.' } \\
4.10 .4 \text { 'I must co-operate in } \\
\text { advancing information processing } \\
\text { by communication with other } \\
\text { professionals, students and the } \\
\text { public, and by contributing to the } \\
\text { efforts of professional and } \\
\text { scientific societies and schools.' }\end{array}$ \\
\hline
\end{tabular}




\begin{tabular}{|c|c|c|}
\hline & $\begin{array}{l}\text { Deontological and teleological } \\
\text { aspects of ACS Code of Ethics }\end{array}$ & $\begin{array}{c}\text { Associated virtue ethics } \\
\text { cluster examples from ACS } \\
\text { Code of Ethics }\end{array}$ \\
\hline $\begin{array}{l}\text { Transformation - } \\
\text { intention of the project }\end{array}$ & $\begin{array}{l}\text { 4.3.5 'I must enhance my own } \\
\text { professional development, and that } \\
\text { of my colleagues, employees and } \\
\text { students.' } \\
\text { 4.5.3 'I must respect the proprietary } \\
\text { nature of the information of others.' } \\
4.8 .6 \text { 'I must not require, or attempt } \\
\text { to influence, any person to take any } \\
\text { action which would involve a } \\
\text { breach of the Code of Ethics.' } \\
4.9 .1-3 \text { 'Professional Development' } \\
\text { involves self-discipline and } \\
\text { resourcefulness to advance from } \\
\text { one's previous mindset. } \\
4.10 .5 \text { 'I must distance myself } \\
\text { professionally from someone } \\
\text { whose membership in the Society } \\
\text { has been terminated because of } \\
\text { unethical behaviour or } \\
\text { unsatisfactory conduct.' }\end{array}$ & $\begin{array}{l}\text { Self-restraint, self-discipline, } \\
\text { courage, patience, } \\
\text { resourcefulness, caring } \\
4.3 .5 \text { 'I must enhance my own } \\
\text { professional development, and } \\
\text { that of my colleagues, employees } \\
\text { and students.' } \\
4.5 .3 \text { 'I must respect the } \\
\text { proprietary nature of the } \\
\text { information of others.' } \\
4.8 .6 \text { 'I must not require, or } \\
\text { attempt to influence, any person } \\
\text { to take any action which would } \\
\text { involve a breach of the Code of } \\
\text { Ethics.' } \\
4.9 . \text { 'Professional Development' } \\
\text { involves self-discipline and } \\
\text { resourcefulness to advance from } \\
\text { one's previous mindset. } \\
4.10 .5 \text { 'I must distance myself } \\
\text { professionally from someone } \\
\text { whose membership in the Society } \\
\text { has been terminated because of } \\
\text { unethical behaviour or } \\
\text { unsatisfactory conduct.' }\end{array}$ \\
\hline $\begin{array}{l}\text { Accountability - } \\
\text { which involves } \\
\text { stakeholders in } \\
\text { evaluating ethical } \\
\text { considerations and } \\
\text { redressing injustices }\end{array}$ & $\begin{array}{l}4.5 .5 \text { 'I must advise my client or } \\
\text { employer of any potential conflicts } \\
\text { of interest between my assignment } \\
\text { and legal or other accepted } \\
\text { community requirements.' } \\
4.5 .6 \text { 'I must advise my clients and } \\
\text { employers as soon as possible of } \\
\text { any conflicts of interest or } \\
\text { conscientious objections which face } \\
\text { me in connection with my work.' } \\
4.8 .3 \text { 'I must respect my employees } \\
\text { and refrain from treating them } \\
\text { unfairly' }\end{array}$ & $\begin{array}{l}\text { Fairness, impartiality, justice, } \\
\text { mercy, harmony, decisiveness, } \\
\text { courage, strength of character } \\
4.5 .5 \text { 'I must advise my client or } \\
\text { employer of any potential } \\
\text { conflicts of interest between my } \\
\text { assignment and legal or other } \\
\text { accepted community } \\
\text { requirements.' } \\
4.5 .6 \text { 'I must advise my clients } \\
\text { and employers as soon as } \\
\text { possible of any conflicts of }\end{array}$ \\
\hline
\end{tabular}




\begin{tabular}{|l|l|l|}
\hline & $\begin{array}{l}\text { Deontological and teleological } \\
\text { aspects of ACS Code of Ethics }\end{array}$ & $\begin{array}{c}\text { Associated virtue ethics } \\
\text { cluster examples from ACS } \\
\text { Code of Ethics }\end{array}$ \\
\hline & $\begin{array}{l}4.10 .6 \text { 'I must take appropriate } \\
\text { action if I discover a member, or a } \\
\text { person who could potentially be a } \\
\text { member, of the society engaging in } \\
\text { unethical behaviour.' } \\
\text { 4.10.7 'I must seek advice from the } \\
\text { Society when faced with an ethical } \\
\text { dilemma I am unable to resolve by } \\
\text { myself.' }\end{array}$ & $\begin{array}{l}\text { interest or conscientious } \\
\text { objections which face me in } \\
\text { connection with my work.' } \\
4.8 .3 \text { 'I must respect my } \\
\text { employees and refrain from } \\
\text { treating them unfairly' } \\
4.10 .6 \text { 'I must take appropriate } \\
\text { action if I discover a member, or } \\
\text { a person who could potentially be } \\
\text { a member, of the society } \\
\text { engaging in unethical behaviour.' } \\
4.10 .7 \text { 'I must seek advice from } \\
\text { the Society when faced with an } \\
\text { ethical dilemma I am unable to } \\
\text { resolve by myself.' }\end{array}$ \\
\hline $\begin{array}{l}\text { Environment - } \\
\text { stakeholders affected } \\
\text { by the (cont.) situation } \\
\text { in which the computer } \\
\text { professional works }\end{array}$ & $\begin{array}{l}\text { could involve implications of IT } \\
\text { work on the environment }\end{array}$ & $\begin{array}{l}\text { Kindness, patience, humanity } \\
\text { 4.5.6 'Conscientious objections' } \\
\text { could involve implications of IT } \\
\text { work on the environment }\end{array}$ \\
\hline
\end{tabular}


Table 3: Soft systems inquiry headings together with the Singapore Computer Society (SCS) Code of Ethics

\begin{tabular}{|c|c|c|}
\hline & $\begin{array}{l}\text { Deontological and teleological } \\
\text { aspects of SCS Code of Ethics }\end{array}$ & $\begin{array}{l}\text { Associated virtue ethics } \\
\text { cluster examples from SCS } \\
\text { Code of Ethics }\end{array}$ \\
\hline $\begin{array}{l}\text { Owner - the eventual } \\
\text { system owner }\end{array}$ & $\begin{array}{l}\text { - 1. SCS members will act at all } \\
\text { times with integrity } \\
-2^{*} \text { adhere to their employer's or } \\
\text { client's standards and guidelines } \\
-4^{*} \text { not speak on behalf of the } \\
\text { Society without proper authority }\end{array}$ & 1. Integrity \\
\hline $\begin{array}{l}\text { Worldview - the } \\
\text { assumptions of those } \\
\text { with influence on the } \\
\text { IT project, such as } \\
\text { management } \\
\text { personnel }\end{array}$ & $\begin{array}{l}\text { - 4. SCS members will act with } \\
\text { professionalism to enhance the } \\
\text { prestige of their profession and the } \\
\text { Society } \\
-2^{*} \text { adhere to their employer's or } \\
\text { client's standards and guidelines } \\
-4^{*} \text { uphold and improve the } \\
\text { professional standards of the } \\
\text { Society through participation in } \\
\text { their formulation, establishment } \\
\text { and enforcement } \\
-4^{*} \text { not seek personal advantage to } \\
\text { the detriment of the Society } \\
-4^{*} \text { not speak on behalf of the } \\
\text { Society without proper authority } \\
-4^{*} \text { not slander the professional } \\
\text { reputation of any other person } \\
-4^{*} \text { will use their special } \\
\text { knowledge and skill for the } \\
\text { advancement of human welfare }\end{array}$ & - 4 Professionalism \\
\hline $\begin{array}{l}\text { Customer - the } \\
\text { system's beneficiary }\end{array}$ & $\begin{array}{l}-2^{*} \text { adhere to their ... client's } \\
\text { standards and guidelines } \\
-2 * \text { indicate to their ... clients the } \\
\text { consequences to be expected if } \\
\text { their professional judgement is } \\
\text { overruled }\end{array}$ & - 2* Professionalism \\
\hline
\end{tabular}




\begin{tabular}{|c|c|c|}
\hline & $\begin{array}{l}\text { Deontological and teleological } \\
\text { aspects of SCS Code of Ethics }\end{array}$ & $\begin{array}{l}\text { Associated virtue ethics } \\
\text { cluster examples from SCS } \\
\text { Code of Ethics }\end{array}$ \\
\hline & $\begin{array}{l}-3^{*} \text { extend public knowledge, } \\
\text { understanding and appreciation of } \\
\text { information technology and oppose } \\
\text { false or deceptive statements } \\
\text { related to information technology } \\
\text { of which they are aware } \\
-4^{*} \text { will use their special } \\
\text { knowledge and skill for the } \\
\text { advancement of human welfare }\end{array}$ & - 4* Beneficence \\
\hline $\begin{array}{l}\text { Actor - the } \\
\text { individual(s) involved } \\
\text { in the system, such as } \\
\text { information systems } \\
\text { professionals }\end{array}$ & $\begin{array}{l}\text { - 2. SCS members will accept full } \\
\text { responsibility for their work. } \\
-3 \text {. SCS members will always aim } \\
\text { to increase their competence. } \\
-4 \text {. SCS members will act with } \\
\text { professionalism to enhance the } \\
\text { prestige of their profession and the } \\
\text { Society } \\
-1^{*} \text { not lay claim to any level of } \\
\text { competence that they do not } \\
\text { possess } \\
-1^{*} \text { act with complete discretion } \\
\text { when entrusted with confidential } \\
\text { information } \\
-1^{*} \text { be impartial when giving } \\
\text { advice and will disclose any } \\
\text { relevant personal interests } \\
-1^{*} \text { give credit for work done by } \\
\text { others where credit is due } \\
-2^{*} \text { carry out their assignments in a } \\
\text { professional manner } \\
-2^{*} \text { adhere to their employer's or } \\
\text { client's standards and guidelines } \\
2^{*} \text { indicate to their employers or } \\
\text { clients the consequences to be } \\
\text { expected if their professional }\end{array}$ & $\begin{array}{l}\text { - 2. Responsibility } \\
\text { - 3. Professional Competence } \\
\text { - 4. Professionalism } \\
-1 * \text { Integrity } \\
-1 * \text { Discretion } \\
-1 * \text { Impartiality } \\
-2 * \text { Professionalism }\end{array}$ \\
\hline
\end{tabular}




\begin{tabular}{|c|c|c|}
\hline & $\begin{array}{l}\text { Deontological and teleological } \\
\text { aspects of SCS Code of Ethics }\end{array}$ & $\begin{array}{l}\text { Associated virtue ethics } \\
\text { cluster examples from SCS } \\
\text { Code of Ethics }\end{array}$ \\
\hline & $\begin{array}{l}\text { judgement is overruled } \\
-3^{*} \text { continue to upgrade their } \\
\text { knowledge and skills, and be aware } \\
\text { of relevant development in the } \\
\text { technology they are involved in } \\
-3^{*} \text { provide opportunity and } \\
\text { encouragement for professional } \\
\text { development and advancement to } \\
\text { fellow professionals and aspirants } \\
\text { to the profession } \\
-3^{*} \text { extend public knowledge, } \\
\text { understanding and appreciation of } \\
\text { information technology and oppose } \\
\text { false or deceptive statements } \\
\text { related to information technology } \\
\text { of which they are aware } \\
-4^{*} \text { uphold and improve the } \\
\text { professional standards of the } \\
\text { Society through participation in } \\
\text { their formulation, establishment } \\
\text { and enforcement } \\
-4^{*} \text { not slander the professional } \\
\text { reputation of any other person } \\
-4^{*} \text { will use their special } \\
\text { knowledge and skill for the } \\
\text { advancement of human welfare }\end{array}$ & - 4* Beneficence \\
\hline $\begin{array}{l}\text { Transformation - } \\
\text { intention of the project }\end{array}$ & $\begin{array}{l}\text {-3. SCS members will always aim } \\
\text { to increase their competence. } \\
-4 \text {. SCS members will act with } \\
\text { professionalism to enhance the } \\
\text { prestige of their profession and the } \\
\text { Society } \\
-3^{*} \text { continue to upgrade their } \\
\text { knowledge and skills, and be aware } \\
\text { of relevant development in the } \\
\text { technology they are involved in } \\
-3^{*} \text { provide opportunity and } \\
\text { encouragement for professional } \\
\text { development and advancement to } \\
\text { fellow professionals and aspirants }\end{array}$ & $\begin{array}{l}\text { - 3. Professional Competence } \\
\text { - 4. Professionalism }\end{array}$ \\
\hline
\end{tabular}




\begin{tabular}{|c|c|c|}
\hline & $\begin{array}{l}\text { Deontological and teleological } \\
\text { aspects of SCS Code of Ethics }\end{array}$ & $\begin{array}{l}\text { Associated virtue ethics } \\
\text { cluster examples from SCS } \\
\text { Code of Ethics }\end{array}$ \\
\hline & $\begin{array}{l}\text { to the profession } \\
-3^{*} \text { extend public knowledge, } \\
\text { understanding and appreciation of } \\
\text { information technology and oppose } \\
\text { false or deceptive statements } \\
\text { related to information technology } \\
\text { of which they are aware } \\
-4^{*} \text { uphold and improve the } \\
\text { professional standards of the } \\
\text { Society through participation in } \\
\text { their formulation, establishment } \\
\text { and enforcement } \\
-4^{*} \text { will use their special } \\
\text { knowledge and skill for the } \\
\text { advancement of human welfare }\end{array}$ & - 4* Beneficence \\
\hline $\begin{array}{l}\text { Accountability - } \\
\text { stakeholders in } \\
\text { evaluating ethical } \\
\text { considerations and } \\
\text { redressing injustices }\end{array}$ & $\begin{array}{l}-2^{*} \text { indicate to their employers or } \\
\text { clients the consequences to be } \\
\text { expected if their professional } \\
\text { judgement is overruled } \\
-4^{*} \text { uphold and improve the } \\
\text { professional standards of the } \\
\text { Society through participation in } \\
\text { their formulation, establishment } \\
\text { and enforcement } \\
-4^{*} \text { not speak on behalf of the } \\
\text { Society without proper authority } \\
-4^{*} \text { will use their special } \\
\text { knowledge and skill for the } \\
\text { advancement of human welfare }\end{array}$ & $\begin{array}{l}\text { - 4* Professionalism } \\
\text { - 4* Beneficence }\end{array}$ \\
\hline Environment - & & \\
\hline
\end{tabular}




\section{Discussion}

While the analysis methodologies have not been formatted in entirely the same way, the general trends can still be detected. For example, the 'CATWOEA' headings are not used in the same order in each of the Codes, and more virtues have been extrapolated from the ACS Code of Ethics, by interpretation, rather than be mere repetition, as has been the case with the SEARCC and SCS codes analysed here. An obvious area for consideration is that of the 'environment' stakeholder heading. The SEARCC Code does not specifically mention the physical environment, but focuses on the goodwill and cooperative ambiance of the desired IT environment, and the improved quality of life that IT can provide to the region. The SCS Code has no specific mention of the environment, and the ACS Code has nothing specific to say about the environment either, but could possibly allow for its consideration under the heading of 'conscientious objection'. There are environmental problems in the South East Asian Region, as in the rest of the world, and the Association for Computing Machinery (ACM) Code of Ethics., for example, does have a section on protecting the environment in which IT plays a part. Examples of how IT can affect the environment are in use of nonrenewable resources, recycling of paper and equipment, avoidance of pollution, and site location for industry. Perhaps this analysis methodology has identified a gap area in the three Codes.

The 'customer' stakeholder seems to be well considered in all of the Codes, with more specific detail in some Codes than in others. There could be a conflict at times, in adhering to the client's standards and guidelines (SCS Code $2 *$ ) and in indicating a disagreement in the results of doing this to the client, when it would go against professional judgement to follow the client's guidelines (SCS Code 2*). Sometimes, the professional does know more, and sometimes the client may be in this enviable position. There may need to be more grounds for renegotiation of contracts in cases where disagreements between professionals and clients are irresolvable. Some IT codes of ethics do have more on grievance procedures and even on 'whistle-blowing' on a stakeholder or two as a very last resort (e.g. ACM Code of Ethics).

Allowance is made in SEARCC for 'actor' Members to adhere to the laws of whatever country they may be working in, which presumably allows for a global perspective, and not just for the SEARCC region itself. There is a strong 'transformation' emphasis in these three Codes, which reflects a vibrant enthusiasm for improvement and further cooperative development. The 'accountability' aspects of a transformative IT improvement are always important, and the SCS Code's emphasis on the 'advancement of human welfare' (SCS Code $4^{*}$ ) is laudable. There is some difference in the 'worldview' focus of the three Codes. The SEARCC Code of Ethics appears to limit its horizon, in accord with its authority, to its own voluntary Code, whereas both the ACS and SCS Codes expand their vision to the good of society in general, when any narrow sectarian interests may threaten it. There is a range of 'owner' considerations in the three Codes. The SEARCC Code focuses on the South East Asian region, while the ACS Codes and the SCS Codes extend this consideration to the profession, and the welfare of the world, with the virtue of 'integrity' in a starring role in all three Codes. 


\section{Conclusion}

Although the methodology used is an art and not a science, it allowed for a general comparison of the SEARCC, ACS and SCS Codes, and identified some similarities and differences, and also a gap in the 'environment' area in all three. It is clear that the three Codes are compatible, and do have the welfare of the wider community, as well as the promotion of the IT profession, at their essence. There are many differences in the Members of SEARCC, and it is recognised that the SEARCC Code of Ethics is able to serve them all well. Such an over-arching Code of IT Ethics and Professional Conduct may be beneficial for the whole global environment in which all IT professionals now work. The Internet, for example, makes the global IT village a reality. It may be the case that the International Federation of Information Processing (IFIP) hope for the development of some over-arching global information ethics guidelines that can become a reality (IFIP; Lee \& Berleur 1994).

\section{References}

Association for Computing Machinery (ACM) Code of Ethics and Professional Conduct. 1992. http://www.acm.org/constitution/c ode.html (accessed July 2003) and www.isworld.org.

Australian Computer Society (ACS) Code of Ethics.

http://www.acs.org.au/national/po spaper/acs131.htm and www.isworld.org (accessed 2003)
Checkland, P. \& Holwell, S. 1998. Information, Systems and Information Systems- Making Sense of the Field. England: John Wiley \& Sons.

IFIP. 1995. 'Regarding Codes of Conduct for Computer Societies', Recommendations to the International Federation for Information Processing from the IFIP Ethics Task Force' http://courses.cs.vt.edu/ cs3604/li b/WorldCodes/IFIP.Recommendat ions.html (accessed August 2003)

Kymlicka, W. 1991. 'The Social Contract Tradition'. Singer, $\mathrm{P}$ (ed.) A Companion to Ethics. UK: Blackwell Publishers, pp. 186-196.

Lee, J. A. N. \& Berleur, J. 1994. 'Progress Towards a World-Wide Code of Conduct'. SIGCAS Conference on Ethics, Gatlinburg TN, November, pp. 11-13.

Singapore Computer Society (S.C.S.) Professional Code of Conduct, http://www/courses.cs.vt.edu/ cs3 604/lib/WorldCodes/Singapore.Co de.html, October 1994 (accessed 2003)

South East Asia Regional Computer Confederation (SEARCC) Code of Ethics, http:// courses.cs.vt.edu/ $\sim$ cs3604/lib/WorldCodes/SEARCC .Code.html, SPIG-PS and SEARCC EXCO June 19, 1993 (accessed 2003) 
Wheeler, S. 2003. 'An Analysis of the Association for Computing Machinery (ACM) Code of Ethics'. Computers and Society, On-Line Magazine of an Association for Computing Machinery (ACM) special interest group SIGCAS (accessed via http://www.acm.org), September.

Wheeler, S. (2004, forthcoming) 'A Multiple Perspective Approach to Ethics in Information Systems', $\mathrm{PhD}$ Thesis, University of South Australia. 